\title{
Protective effect of Star Anise Seeds on Cadmium Induced Changes on Blochemical parameters of Rat
}

\author{
By \\ Shimaa F.A.E Ghozy \\ Home Economics Dept., Faculty of Specific \\ Education, Mansoura University, Egypt.
}

Research Gournal Specific Fducation

Faculty of Specific Education

Mansoura University

ISSUE NO. 45, JANUARY. 2017

مجلة بحوث التزبية النوعية - جامعة المنصورة

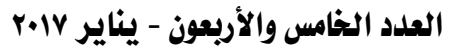


= protective effect of star anise seeds on cadmium induced changes on biochemical parameters of rat 


\section{Protective effect of Star ANISE Seeds on Cadmium Induced Changes ON BIOCHEMICAL PARAMETERS OF RAT}

\section{Shimaa F.A.E Ghozy*}

\section{Abstract}

Objective: The purpose of present study was to investigate the protective efficacy of star anise seed (SAS) on oxidative stress induced by cadmium in rats.

Methods: Thirty five of white male albino rats were divided to 5 groups: negative, $\mathrm{CdCl}_{2}$ (5mg/kg b.w) control, $\mathrm{CdCl}_{2}+\mathrm{SAS}(50 \mathrm{~g} / \mathrm{kg}$ diet), $\mathrm{CdCl}_{2}+\mathrm{SAS}(100 \mathrm{~g} / \mathrm{kg}$ diet $)$ and $\mathrm{CdCl}_{2}+\mathrm{SAS}(150 \mathrm{~g} / \mathrm{kg}$ diet $)$. The rats were feeding on star anise seeds daily for a period of 6 weeks. The variation in lipid profile, the biomarkers of liver and renal function, lipidperoxidation, SOD, total antioxidant capacity and acetylcholinesterase concentration were studied. As well as, histological assay of liver, kidney and brain in rats.

Result: Cadmium toxicity induces significant increase in serum lipid profile parameters except HLDL-C, ALT, AST, urea, creatinine, uric acid, MDA, AChE levels. Moreover, significant decrease in body weight gain, HLDL-C, SOD and total antioxidant capacity. Results of the histological examination of liver, renal and brain also support the above findings.

Conclusion: The current study suggests that star anise seed powder may be beneficial with promising prospect as a preventative antioxidant agent to resist oxidative damages induced by cadmium in rats.

Keywords: Star anise, cadmium chloride; oxidative stress; acetylcholinesterase; lipid peroxidation

\section{INTRODUCTION}

Both humans and animals reacts with their environments every day and also are exposed to a wide range of synthesis chemicals existing in the air, food and water (Kaoud $\boldsymbol{e t}$ al., 2010). One of the most widespread metals that cause the toxicity of the environment and contaminated from industrial

\footnotetext{
* Home Economics Dept., Faculty of Specific Education, Mansoura University, Egypt.
} 
is cadmium, a heavy intoxicate metal evolves an early oxidative damages which, later contribute to the development of disease status to the most serious problems (Elgaml and Hashish, 2014). Various authenticated reports have shown that cadmium caused diverse genotoxicity effects including, chromosomal distortions and DNA deterioration, renal damage, bone disease and various kinds of cancer are imputed to excessive exposure to cadmium (Oyinloye et al., 2016). Even though, there are plenty of studies that examined the effect of cadmium in experimental animals and few studies on emergence and the beginning of cadmium pollution in communities, its molecular mechanization of work are not completely explicated (Skipper et al., 2016). Cadmium chloride associated with oxidative stress which led to serious problems in different organs. The International Agency for Research on Cancer has been deemed it as a human carcinogenic and falls within the first batch of metals causing cancer (Onwuka et al., 2010). Cadmium toxicity in human beings commonly happens by inhaling tobacco smoke and consumed of polluted food and water. Sever poisoning of cadmium associated with lung, renal and hepatic disorders (Kasuya et al., 2000). Meanwhile deep-seated toxicity may result in crippling of lung injury, disruption of metabolism, dysregulation of the pressure of blood, renal dysfunction and immune disorders (Morshedi $\boldsymbol{e t}$ al., 2014).

Free radicals play a major role in causing many human illnesses, including atherosclerosis, nerve, carcinoma and senility disorders. Free radicals and reactive oxygen particles are produced by different endogenous systems in our body as a result of exposure to some chemical or pathogens (Singh et al., 2015). An antioxidant is known as a molecule steady enough to donate an electron to a free radical and equalized it, therefore decreasing its ability to causing harm to different tissues. These molecules prevent or postponed cell damage fundamentally through their activity as free radical scavenging (Attia et al., 2014). The word of oxidative stress is the status of oxidative damage creating when the balance between free radical obstetrics and antioxidant system is undesirable, resulting injury to various molecular 
types such as proteins, fats and nucleic acids (Breitenbach and Eckl, 2015).

To date, there is no effective medication to treat cadmium toxicity (Elgaml and Hashish, 2014). Interest has increased recently to discover the functional activities of the various medicinal plants herbs which return to its natural source, efficacy and slight adverse effects (Singh, 2011). Medicinal and aromatic plants as herbal and spices, are consider as gift of nature, and use to protect from different disorders and infections since ancient times due to containing huge numbers of vital compounds with free radical scavenging molecules (Goel, 2013). Only minority of these plants species studied for biochemical characteristics and laboratory experiments are even less (Lalitha et al., 2010). Plant kingdom represents an extraordinary resource of innovative molecules (Madhu et al., 2014). Among myriad of plants staranise seeds (Illicium verum Hook) of Magnoliaceae family is a small evergreen tree, and commonly named star anise, star aniseed. The star anise is used as spice throughout the world. It is native of Egypt, Greece, Crete and Asia Minor and was transported by the ancient Egyptians to different parts of the world (Mohamed et al., 2015). The plant used widely in food and curative intents, therefore take as a natural therapy by some patients. The plant was used in conventional remedy for remediation of skin inflammation, colic, puke, rheumatic troubles, sleeplessness, antiulcer and antibacterial (Matsui et al., 2007; Huang et al., 2010; Wang et al., 2011; Sung et al., 2012 and Hussaini et al., 2013).

various contemporaneous pharmaceutical clues have asserted bioactive compounds founded in star anise such as polysaccharides, essential oils and vital acids and considered it as unique spice thus, the plant is used in numerous applications such as anti-oxygenic, anticarcinogenica and Hypolipidemic properties (Liu et al., 1997; Li et al., 2006; Li et al., 2008; Shu et al., 2010; Madhu et al,. 2014; Bi et al., 2015 and Park et al., 2015).

Due to the antioxidant activities of star anise seed, it was thought to be worthwhile to study the possible effects on oxidative stress induced by 
$=$ protective effect of star anise seeds on cadmium induced changes on biochemical parameters of rat $=$

cadmium in rats. Therefore, the current work was carried out to evaluate the effect of star anise seed with different levels on biochemical parameters and oxidative stress in cadmium exposed rats.

\section{Materials and Methods}

\section{Materials}

Star anise seeds (Illicium Verum), were purchased as dried material from local herbs market in Cairo Egypt.

Cadmium chloride (CdCl2), was obtained from Sigma Chemical Co. (St Louis, Mo, USA).

Animals: Thirty five male rats of Sprague-Dawley strain, their weighted $145 \pm 5 \mathrm{~g}$. The animals were kept in standard condition, cages of plastic , maintained on a natural light-dark cycle at room temperature of 26 $\pm 2^{\circ} \mathrm{C}$ and fed basal diet according to (Reeves et al., 1993) and water $a d$ libitum. Animals were retained to acclimatize for a period of one week.

\section{Methods:}

Preparation of plant seed: Star anise seeds were crushed in a blender to give a powder and kept in dusky stoppered bottles of glass in a dry place and dark location till use, according to (Russo, 2001).

Proximate analysis: Star anise seed was analyzed for the moisture, fat, protein, ash, and fiber contents. The carbohydrates as nitrogen free extract were determined as described in (AOAC, 2000).

\section{Experimental protocol:}

The experiment was carried out in Animal House in the Food Technology Research Institute, Agriculture Research Center, Giza. After the acclimatization period, animals were divided randomly to two major groups, the first major group: ( $n=7$ rats) fed on standard diet only as negative (normal group) and intraperitoneally injected with saline solution. While, the second major group ( $\mathrm{n}=28$ rats) were injected intraperitoneally with $\mathrm{CdCl}_{2}$ (5 mg/kg b.wt) daily to induce Cadmium chloride toxicity, according to (Hew et al., 1993). Then, divided into 4 subgroups each comprising of 7 rats as follows: 
$\mathbf{C d C l}_{2}$ control group: was kept without any treatment as $\left(\mathrm{CdCl}_{2}\right.$ group) and fed on basal diet.

$\mathbf{C d C l}_{2}+\mathbf{S A S}\left(50 \mathrm{~g} / \mathrm{kg}\right.$ diet) group: intoxicated rats with $\mathrm{CdCl}_{2}$ that fed on standard diet contained $5 \%$ star anise seeds

$\mathrm{CdCl}_{2}+\mathrm{SAS}\left(\mathbf{1 0 0 g} / \mathrm{kg}\right.$ diet) group: intoxicated rats with $\mathrm{CdCl}_{2}$ that fed on standard diet contained $10 \%$ star anise seeds

$\mathrm{CdCl}_{2}+\mathrm{SAS}\left(\mathbf{1 5 0 g} / \mathrm{kg}\right.$ diet) group: intoxicated rats with $\mathrm{CdCl}_{2}$ that fed on standard diet contained $15 \%$ star anise seeds

Throughout the duration of experiment body weight was monitored weekly and feed intake was measured daily and both were determined according to (Chapman et al., 1959).

\section{Blood serum collection:}

Animals were sacrificed by ether anesthesia at the end period of the study (6 weeks), samples of blood were collected from hepatic vein, small part was taken into heparinised tube and the remainder were centrifuged at $3000 \mathrm{rpm}$ to take serum that separated carefully and transferred to clean plastic tubes and frozen at $-20^{\circ} \mathrm{C}$ until analysis.

\section{Biochemical assays:}

Determination of serum lipid profile: Triglyceride, Total cholesterol, high density lipoprotein, very low density lipoproteins and low density lipoproteins were carried out by colorimetric method according to (Fossati and Prencipe, 1982; Allian et al., 1974; Fnedewaid, 1972 and Lee \& Nieman 1996), respectively.

Determination of liver enzymes: Serum aspartate and alanine aminotransferases were estimated according to (Reitman and Frankel 1957).

Determination of renal functions: Serum urea, uric acid and creatinine, uric acid and urea were determined according to (Patton and Crouch, 1977; Fossati et al., 1980 and Bohmer, 1971), respectively.

Determination of serum antioxidant parameters and acetylcholinesterase: Malondialdehyd, total antioxidants capacity and 
$=$ protective effect of star anise seeds on cadmium induced changes on biochemical parameters of rat $=$

superoxide dismutase activity were determined according to (Ohkawa $\boldsymbol{e t}$ al., 1979; Cao et al., 1993 and Nishikimi et al., 1972), respectively. Acetylcholinesterase (AchE) activity was determined according to (Knedel and Boottger 1967).

Histological Examination: At the end of the study, tissue samples of all rats from liver, kidney and brain were collected and fixed in neutral buffered formalin, processed by conventional method according to (Bancroft et al., 1996).

Statistical analysis:

Data were statistically analyzed using SPSS (Soft-Ware, SAS Institute, Cary, NC). Effects of different treatments were analyzed by one way ANOVA (Analysis of variance) test using Duncan's multiple range test and $\mathrm{p}<0.05$ was used to indicate significance between different groups (Snedecor and Cochran, (1967).

\section{RESULTS}

\section{1 - Proximate composition of star anise seed powder (dry basis \%)}

The results in (Table.1) represented the proximate analysis of star anise seed expressed in percentage, showed the moisture was $1.37 \%$, crude protein content was $19.64 \%$, fat recorded $2.91 \%$, crude fibre recorded $8.11 \%$, total ash was $6.35 \%$ and nitrogen free extract content was $55.92 \%$. Therefore the naturtional analysis of the star anise seed establishes that anise seed can be ranked as rich source of protein, crude fiber and ash due to their relatively high contents, which increase their nautrional value.

Table 1: Proximate composition of star anise seed (SAS) (dry basis \%)

\begin{tabular}{|cc|}
\hline Characteristics & Content \% \\
\hline Moisture & 1.37 \\
Crude protein & 19.64 \\
Crude fat & 2.91 \\
Crude fiber & 8.11 \\
Total ash & 6.35 \\
Nitrogen free extract & 55.92 \\
\hline
\end{tabular}


مجلة بحوث التربية النوعية - عدد 0؛ - يناير r.

\section{2 - Effect of treatment with star anise seed (SAS) on feed intake and body weight gain of rats received $\mathrm{CdCl}_{2}$}

The weight was evaluated for 6 successive weeks, the results in Fig.1 showed that normal control group had the higher body weight gain , in contrary we observed that the cadmium control group represented the lower body weight, however in groups recevied star anise seed, it noted a significant increase in the body weight gain compared $(\mathrm{p}<0.05)$ to cadmium (intoxicated) group. Concerning feed intake (Fig.1), the data shows that cadmium induced a reduction in feed intake when compared to negative $(\mathrm{p}<0.05)$, whereas in the treated group with stare anise seed with different levels $(50,100$ and $150 \mathrm{~g} / \mathrm{kg}$ diet), we had observed a significant increase $(\mathrm{p}<0.05)$ compared to intoxicated group $\left(\mathrm{CdCl}_{2}\right)$.

\section{3 - Effect of treatment with star anise seed (SAS) on serum lipid profile of rats received $\mathrm{CdCl}_{2}$}

Serum lipid profile in rats received CdCL2 is shown in Fig. 2. administration of cadmium chloride caused significant rise in total cholesterol, triglycerides, LDL-c and VLDL-c levels in cadmium control group, Whereas, a significant diminish in the HDL level was shown in the untreated rats compared to negative rats $(p<0.05)$. These levels were found to be restored in the treated group with satr anise seed and stare anise seed treated group in a concentration dependent manner with $100 \mathrm{~g} / \mathrm{kg}$ diet to be the most effective concentration (Fig.2).

\section{4 - Effect of treatment with star anise seed (SAS) on some liver and renal functions of rats received $\mathrm{CdCl}_{2}$}

The data of the study (Table 2) showed that feeding on diet contained (50, 100 and $150 \mathrm{~g} / \mathrm{kg}$ diet) star anise seed caused significant reduction ( $\mathrm{p}<0.05)$ in ALT and AST activities as compared to $\mathrm{CdCl} 2$ rats (untreated). On other hand the activities of ALT and AST enzymes decreased gradually with increasing level of star anise seed. The $100 \mathrm{~g} / \mathrm{kg}$ diet of star anise seed is more effective in reducing the concentration of ALT. treatment of $\mathrm{CdCl} 2$ intoxicated rats with 50,100 and $150 \mathrm{~g} / \mathrm{kg}$ diet star anise seed decreased AST enzyme by about (46.33\%, $45.01 \%$ and 
$43.02 \%)$ and ALT by about (48.33\%, 38.67\% and 46.12\%) comparing with $\mathrm{CdCl} 2$ control group. These results confirmed with histological findings, as shown in (Fig. 5 D, E) as the increased AST and ALT activities is linked exclusively to necrotic changes in the parenchmal cells of the liver. from these results, it could be conculded that, treating intoxicated $\mathrm{CdCl} 2$ rats with star anise seed with 100 and $150 \mathrm{~g} / \mathrm{kg}$ dietimproved liver enzymes which assoicated with maintended liver tissue.

A significant $(\mathrm{p}<0.05)$ elevation in activities of renal function were observed in $\mathrm{CdCl}_{2}$ control group (untreated), indicate renal dysfunction compared with normal rats. Treatment with star anise seed powder $(50,100$ and $150 \mathrm{~g} / \mathrm{kg}$ diet $)$ showed a significant $(\mathrm{p}<0.05)$ decrease in serum creatinine, urea and uric acid levels towards normalization and close to the negative group (Table 2). In fact, these data are in parallel with histological results (Fig. $6 \mathrm{D}, \mathrm{E}$ ) that shows treatment with 100 and $150 \mathrm{~g} / \mathrm{kg}$ diet star anise seed powder maintained compact glomeruli and well formed renal tubules.

\section{5 - Effect of treatment with star anise seed (SAS) on the activities of antioxidants parametes and Acetyl cholinesterase (AChE) of rats received $\mathrm{CdCl}_{2}$}

For the SOD activity (Table 3), we can observed that cadmium poisoning induced depletion in the enzyme activity from $188.23 \mathrm{U} / \mathrm{Ml}$ in normal control rats to $124.33 \mathrm{U} / \mathrm{mL}$ (cadmium control rats ) ( $<<0.05$ ). Hence, non-significant difference of SOD was observed after treatment of rats with $150 \mathrm{~g} / \mathrm{kg}$ diet star anise seed as compared to negative group, therefore the plant seed rise the level of SOD $(124.33 \mathrm{U} / \mathrm{mL})$ in cadmium control to $(184.33 \mathrm{U} / \mathrm{mL})$ in treated group star anise seed with $150 \mathrm{~g}$ $(\mathrm{p}<0.05)$.

The alterations occurring in total antioxidant capacity in different groups of rats are shown in (Table 3 ). The total antioxidant capacity concentration is significantly reduced $(\mathrm{p}<0.05)$ in intoxicated $\mathrm{CdCl}_{2}$ group compared to negative group. Treatment of $\mathrm{CdCl} 2$ intoxicated rats with star anise seed powder at different levels had a very high significant influence in 
total antioxidant capacity $(\mathrm{p}<0.05)$ comparing with untreated $\mathrm{CdCl} 2$ rats. The results of antioxidant defence system well confirmed with histology data in (Fig. 7 D, E) which showed well formed layers, epineurium and endoneurium in rat brain.

Fig. 3 showed the levels of MDA in plasma of recived CdCL2 rats. MDA is an indicator of lipidperoxidation, after 6 consecutive weeks significant increase in MDA concentration was observed in intoxicated group $(11.05 \pm 1.16 \mathrm{mmol} / \mathrm{L})$ compared to normal control group $(4.37 \pm 0.76$ $\mathrm{mmol} / \mathrm{L})$. Hence, the MDA concentration decreased from $11.05 \mathrm{mmol} / \mathrm{L}$ for intoxicated group to $4.76 \mathrm{mmol} / \mathrm{L}$ in treated group with $150 \mathrm{~g} / \mathrm{kg}$ diet star anise seed. A significant reduction of MDA in groups treated with star anise at levels (50,100 and $150 \mathrm{~g} / \mathrm{kg}$ diet) comparatively to intoxicated group (cadmium alone) $(\mathrm{p}<0.05)$.

The AChE concentrations in all groups are shown in (Fig.4). Exposure to cadmium chloride caused an increase in AChE level of the intoxicated $\mathrm{CdCl}_{2}$ rats (control) comparing with negative group $(\mathrm{p}<0.05)$. While after treatment with star anise seed powder with $10 \%$ and $15 \%$ in diet depleted the AChE levels by $41.1 \%$ and $66.2 \%$ which were statically significant.

Table 2: Effect of Star anise seeds on liver and kidney functions in rats received $\mathrm{CdCl}_{2}$

\begin{tabular}{||c|c|c|c|c|c||}
\hline Parameters & AST & ALT & Creatinine & Urea & Uric acid \\
\hline Groups & \multicolumn{2}{|c|}{$(\mathbf{I u} / \mathbf{m l})$} & \multicolumn{3}{|c|}{$\mathbf{m g} / \mathbf{d l}$} \\
\hline \hline Normal control & $42.67 \pm 8.50^{\mathbf{c}}$ & $37.67 \pm 3.21^{\mathbf{c}}$ & $1.02 \pm 0.07^{\mathbf{b}}$ & $42.67 \pm 3.06^{\mathbf{c}}$ & $2.73 \pm 0.78^{\mathbf{b}}$ \\
\hline $\mathbf{C d C l} \mathbf{2}$ control & $78.67 \pm 9.07^{\mathbf{a}}$ & $74.67 \pm 6.81^{\mathbf{a}}$ & $1.97 \pm 0.31^{\mathbf{a}}$ & $70.03 \pm 2.65^{\mathbf{a}}$ & $5.20 \pm 0.52^{\mathbf{a}}$ \\
\hline $\mathbf{C d C l}_{\mathbf{2}}+\mathbf{S A S}(\mathbf{5 0 g} / \mathbf{k g}$ diet) & $46.33 \pm 6.03^{\mathbf{b}}$ & $48.33 \pm 8.92^{\mathbf{b}}$ & $1.30 \pm 0.17^{\mathbf{b}}$ & $56.11 \pm 3.21^{\mathbf{b c}}$ & $2.79 \pm 0.72^{\mathbf{b}}$ \\
\hline $\mathbf{C d C l}_{\mathbf{2}}+\mathbf{S A S}(\mathbf{1 0 0 g} / \mathbf{k g}$ diet)$)$ & $45.01 \pm 7.32^{\mathbf{b}}$ & $38.67 \pm 8.08^{\mathbf{b c}}$ & $1.17 \pm 0.06^{\mathbf{b}}$ & $56.01 \pm 8.46^{\mathbf{b c}}$ & $2.80 \pm 0.46^{\mathbf{b}}$ \\
\hline $\mathbf{C d C l}_{\mathbf{2}}+\mathbf{S A S}\left(\mathbf{1 5 0 g} / \mathbf{k g ~ d i e t}^{\mathbf{b}}\right)$ & $43.02 \pm 3.46^{\mathbf{c}}$ & $46.12 \pm 9.64^{\mathbf{b c}}$ & $1.41 \pm 0.22^{\mathbf{b}}$ & $61.67 \pm 6.35^{\mathbf{a b}}$ & $3.82 \pm 0.93^{\mathbf{a b}}$ \\
\hline \hline
\end{tabular}

Values are expressed as mean $\pm S D$ SAS: Star Anise Seed

Values which don't share the same letter in each column are significantly different at $p<0.05$.

AST: Aspartate aminotransferases ALT: Alanine aminotransferases 
= protective effect of star anise seeds on cadmium induced changes on biochemical parameters of rat

Table 3: Effect of star anise seeds on total antioxidant capacity and SOD activities in rats received $\mathrm{CdCl}_{2}$

\begin{tabular}{|c|c|c||}
\hline Parameters & \multirow{2}{*}{$\begin{array}{c}\text { Total antioxidants } \\
\text { (mmol/L) }\end{array}$} & $\begin{array}{c}\text { SOD } \\
\text { (U/mL) }\end{array}$ \\
\hline \hline Normal control & $3.14 \pm 0.75 \mathrm{a}$ & $188.23 \pm 12.74 \mathrm{a}$ \\
\hline $\mathbf{C d C l}$ control & $1.17 \pm 0.55 \mathrm{~d}$ & $124.33 \pm 12.01 \mathrm{~d}$ \\
\hline $\mathbf{C d C l}_{\mathbf{2}}+\mathbf{S A S}(\mathbf{5 0 g} / \mathbf{k g}$ diet) & $1.93 \pm 0.65 \mathrm{c}$ & $147.12 \pm 13.01 \mathrm{c}$ \\
\hline $\mathbf{C d C l}_{\mathbf{2}}+\mathbf{S A S}$ (100g/kg diet) & $2.71 \pm 0.09 \mathrm{~b}$ & $167.01 \pm 12.10 \mathrm{~b}$ \\
\hline $\mathbf{C d C l}_{\mathbf{2}}+\mathbf{S A S}(\mathbf{1 5 0 g} / \mathbf{k g}$ diet) & $2.93 \pm 0.68 \mathrm{a}$ & $184.33 \pm 14.15 \mathrm{a}$ \\
\hline
\end{tabular}

Values presented as mean \pm SD SAS: Star Anise Seed

Values which don't share the same letter in each column are significantly different at $p<0.05, S O D$ :

Superoxide dismutase

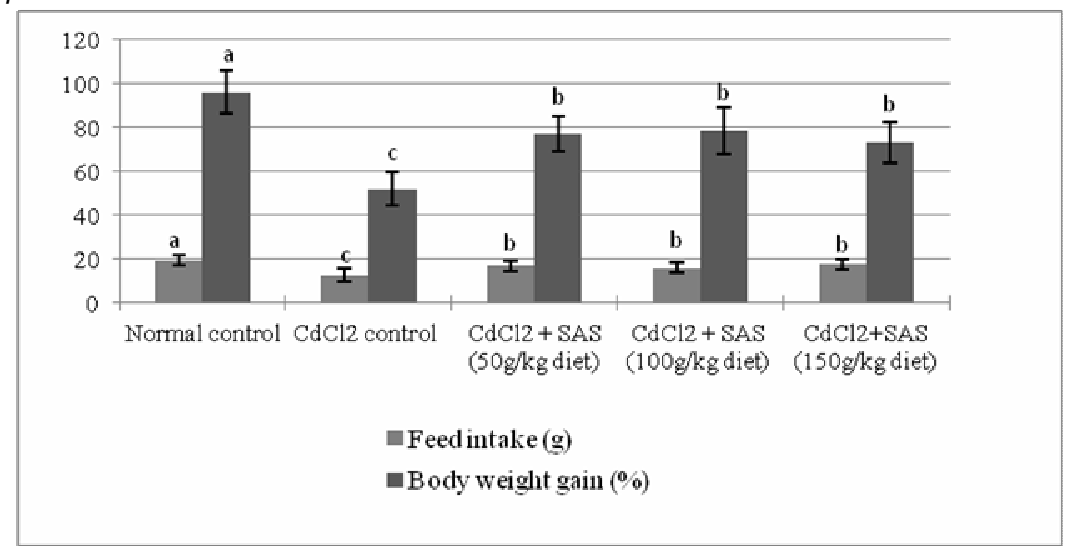

Fig. 1: Effect of star anise seed on feed intake and weight gain in received $\mathrm{CdCl}_{2}$ rats, Values presented as mean $\pm S D$, SAS: Star Anise Seed, The different letters in bar groups significant different at $p<0.05$ 


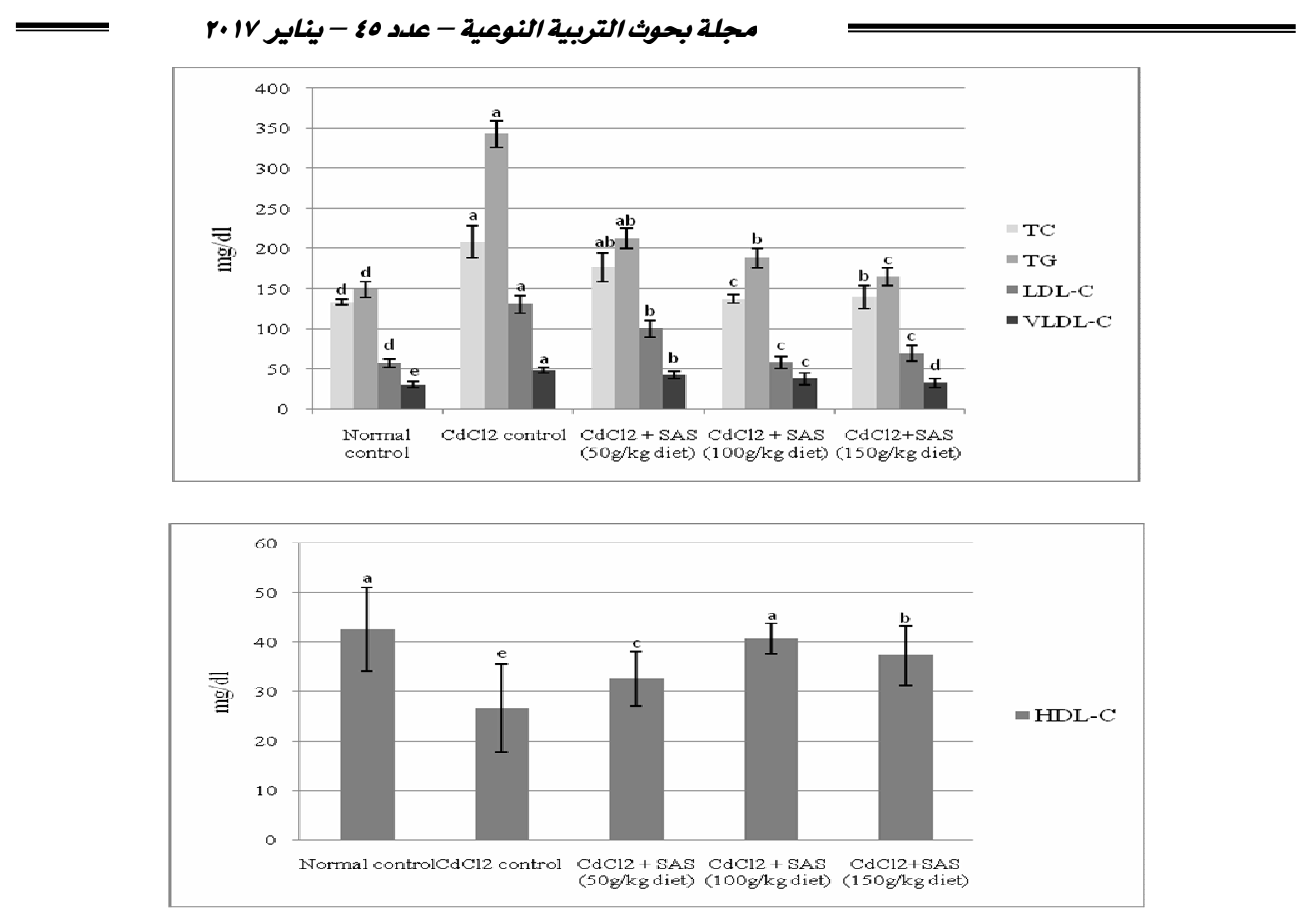

Fig. 2: Effect of star anise seed on serum lipid profile in received $\mathrm{CdCl}_{2}$ rats, Values presented as mean \pm SD, SAS: Star Anise Seed, The different letters in bar groups significant different at $p<0.05$

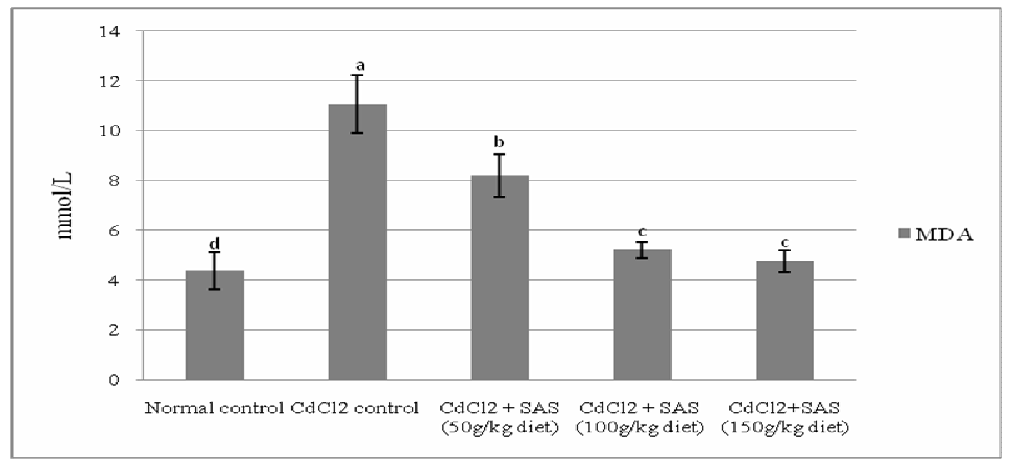

Fig. 3: Effect of star anise seed on serum lipdperoxidation (MDA) in received $\mathrm{CdCl}_{2}$ rats, Values presented as mean $\pm S D$, SAS: Star Anise Seed, The different letters in bar groups significant different at $p<0.05$, MDA: Malondialdehyde 
$=$ protective effect of star anise seeds on cadmium induced changes on biochemical parameters of rat

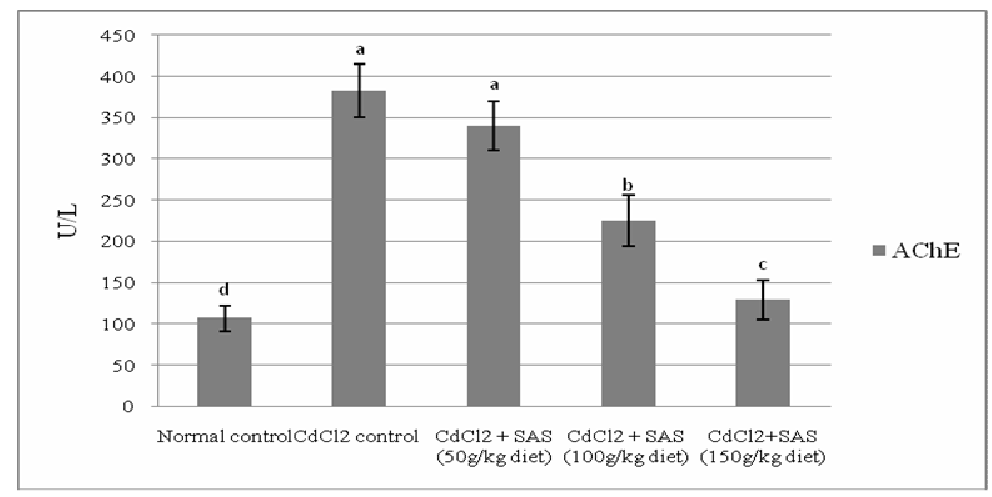

Fig. 4: Effect of star anise seed on serum acetylcholinesterase (AChE) in received $\mathrm{CdCl}_{2}$ rats, Values presented as mean $\pm S D$, SAS: Star Anise Seed, The different letters in bar groups significant different at $p<0.05$

\section{DISCUSSION}

Currently, antioxidative remedy, basically, antioxidants from natural sources are used as reasonable curative application for the protecting and curing of different disorders related to oxidative stress that contribute on starting and development of tissues injuries (Li et al., 2015). Medicinal plants posses their preventive effects by reduce oxidation and improvement antioxidant system. Oxidative stress induced by cadmium is considered as the first stage of causing damage to different organs (Liu et al., 2008 and Oyinloye et al., 2016). Cadmium represents a major occupational risk found in soil, air, water and food. Various studies indicated that cadmium cholride enhance the capability that affect in activation of different coding pathways and in free radicals production, which direct to oxidative stress condition in experimental animals (Valko et al., 2005 and Somade et al., 2014).

Cadmium pollution is growing increasely and considered serious concern to public health all over the world (Hao et al., 2015). Several studies decoumented that long-term exposure to cadmium results in numerous sever side effects in different organs functions including liver, brain, renal, lung, cardiovascular, immune, hematopoietic and reproduction system (Fowler, 2009 and Satarug et al., 2010). Exposure to cadmium chloride shows a significant reduction in body weight gain of $\mathrm{CdCl} 2$ control 
rats. The results was in agreement with previous work by Milton Prabu $\boldsymbol{e t}$ al. (2012) who indicated a marked decline in body weight on cadmium chloride treated experimental animals.

The current study showed that exposure to cadmium mutate the lipid profile as noticed in levels of TG, TC, LDL-c and VLDL-c which significantly elevated and deminished HDL-c level in CdCL2 group. In various studies cadmium has been linked with dyslipidemia and the data of the current work were also in harmony with these reports obtanied by (Rogalska et al., 2009; Chatterjee et al., 2013 and Abdel Moneim et al., 2014). After feeding with star anise seed the abnormalities of lipid profile were ameliorated in cadmium intoxicated rats. Furthermore (Park $\boldsymbol{e t}$ al., 2015) who reported that star anise considered alternative curative strategy in hyperlipidmia associated with atherosclerosis disorders. In addition Vecchio et al., (2016) indicated that star anise contains phytochemical compounds as anethole that shows many functions such as antihyperlipidemic and antioxidative activities.

Liver enzymes levels in serum represented trusted approach for diagnosis the damage of liver. Two liver enzymes studied, ALT and AST detected an ascending tendency in cadmium exposure rats in the current study. Similar finding was observed earlier (Hristev et al., 2007 and Hassan et al., 2012). Meanwhile, feeding $\mathrm{CdCl} 2$ intoxicated rats with star anise seed decrease AST and ALT levels near to normal levels. In addition (Yadav and Bhatnagar, 2007; Aggarwal et al., 2008 and Aboelnaga, 2015) reported that serum AST, ALT and ALP levels decreased by anise seed treatment that increased antioxidants activity in rats which suffer from hepatotoxicity.

The above results of hepatic enzymes biomarkers exhibited a significant positive correlation with histological findings of liver, as observed in the present work, exposure of $\mathrm{CdCl} 2$ caused hepatocellular injury as observed of sever hepatocyte necrosis, degeneration signals and leakage the cell inflammation. These results were similarlly to previous reports (Ayensu and Tchounwou, 2006; Jadhav et al., 2007; Gong et al., 
$=$ protective effect of star anise seeds on cadmium induced changes on biochemical parameters of rat $=$

2008; Renugadevi and Prabu, 2010 and El-Refaiy \& Eissa, 2013) since they documented that $\mathrm{CdCl} 2$ resulted in sever hepatic dysfunction.

Biochemical parameters assessed in the present study for renal function revealed pronounced elevation in some kidney function, uric acid, urea and creatinine levels in $\mathrm{CdCl} 2$ control animals confirmed kidney dysfunction. These results were well upheld by findings of (Toman et al., 2011; Usuda et al., 2011 and Alam and Hendawi, 2015). However star anise seed consumption at levels of $10 \%$ and $15 \%$ reduce the damage and inverted the drop of renal dysfunction induced by $\mathrm{CdCl} 2$ in rats. These data are agree with other report by (Aboelnaga, 2015) who stated that creatinine, uric acid and blood urea nitrogen levels decreased by anise seed treatment to rats which suffer from hepatotoxicity.

Antioxidant enzymes are very necessary for cellular response to tackle oxidative stress under normal and histopathological conditions. Thus, SOD enzyme is used as indicator to evaluate the oxidative stress status ( $\mathbf{L i}$ et al., 2015). In this study, star anise seed caused to weaken the formation of MDA and increased SOD activity which possibly related to its intrinsic antioxidant properties. Results are compatible with findings obtained by (Kanter et al., 2009 and Attia et al., 2014). Lipidperoxidation is one of the main causes of free radical interpose damage that directly destroy neuronal membranes and produced a number of secondary products responsible for wide cellular injury (Sultana $\boldsymbol{e t}$ al., 2013). It has been reported that cadmium caused toxicity via various courses resulted to rise in lipidperoxidation in erythrocytes and tissues membranes, which including liver, renal, testis and brain (Somade et al., 2014).

Alterations in Acetylcholinestrase activity are symptomatic to decline cholinergic function (Slechta and Pokora, 1995). Data in current work observed that cadmium exposure caused significant increase on activity of AChE in rat plasma which is in parallel with findings obtained by (Carageorgiou et al., 2004; Shagirtha et al., 2011 and Alam \& Hendawi, 2015). Meanwhile the results are disagreement with (Rajkumar Milton, 2011 and Gupta et al., 2016) who indicated the AChE activity was 
decreased in rats exposure to cadmium at dose of $2 \mathrm{mg} / \mathrm{kg} \mathrm{b} . \mathrm{w}$, the variation of results may related to the change in the course of administration or the large dose associated with different response of AChE activity in rats.

The present study revealed that feeding on star anise seed powder with $10 \%$ and $15 \%$ to $\mathrm{CdCl} 2$ exposure rats increased total antioxidant, SOD and decreased AChE activities, as well as alleviated lipidperoxidation as confirmed by diminished MDA concentration. Hence, it was revealed that treating with star anise seed showed curative activity against cadmium induced changes in biochemical parameters and oxidative stress. Treatment with SAS may give protection against oxidative stress by boosting antioxidant defense system. These findings suggest the protective role of star anise seed which may be due to the antioxidant action of bioactive compounds from the seed that act by neutralizing ROS (Yang $\boldsymbol{e t}$ al., 2012; Aboelnaga, 2015 and Aly et al., 2016).

\section{CONCLUSION}

In a nutshell, cadmium exposure results in adverse effects on all biochemical parameters. The data of the current work demonstrated that star anise seed have amiolerated effect ont oxidative stress disorders caused by cadmuim choloride intoxication by rising the endogenous antioxidant defence system with subsequent restoration of MDA, SOD, AChE and total antioxidant capcity. In addation star anise seed restored the histological strcuture of liver, renal and brain. These effects could be due to the antioxidant potential of star anise seed, which was related to their content of bioactives molecules. Furthermore studies to identified the bioactive components of star anise and evaluate their therapeutic effects in human models. 


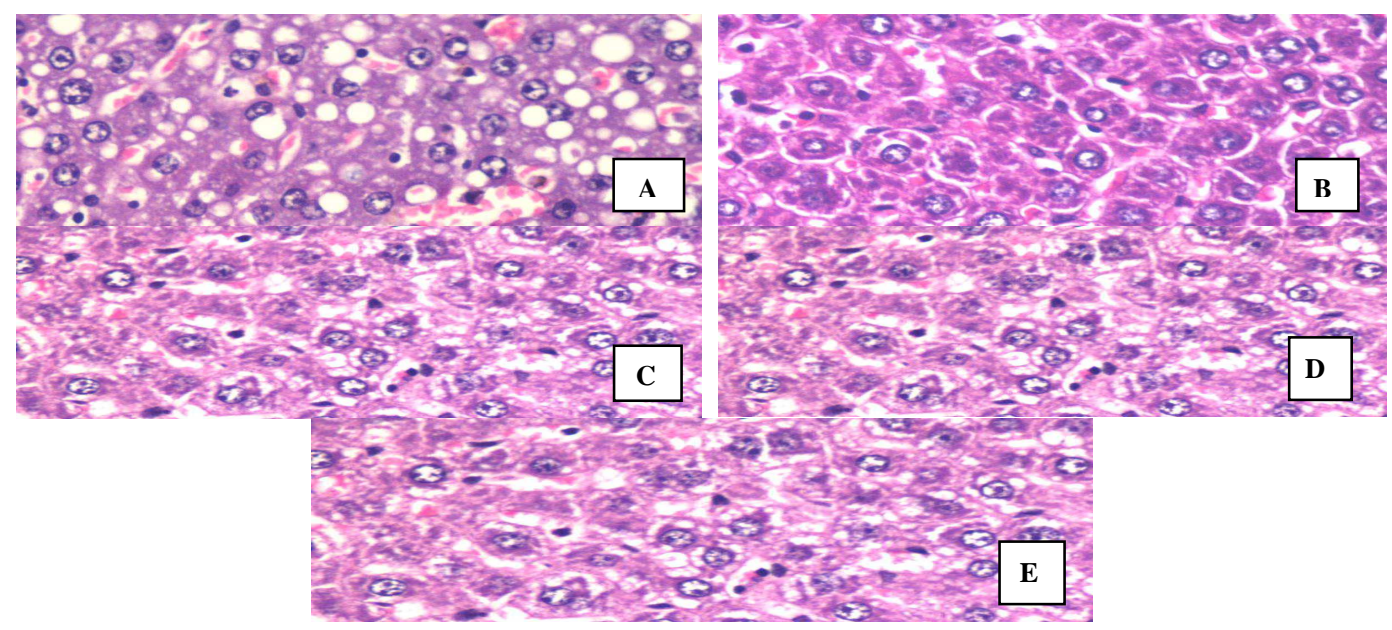

Fig. 5. (A) liver in negative group showed normal histology structure of hepatic lobule ( $\mathrm{H}$ and $\mathrm{E} X 400$ ), $\mathrm{CdCl} 2$ rat shows enlargement in sinusoidal leucocytosis (H and E X400)) (B), CdCl2 +50g star anise $/ \mathrm{kg}$ diet shows kupffer cells activation (H and E X400) (C), (D) $\mathrm{CdCl}+100 \mathrm{~g}$ star anise $\mathrm{kg}$ diet cuboidal hepatocytes were seen ( $H$ and $E$ X400) and (E) CdCl2 +150g star anise/kg diet showed hexagonal hepatocytes and clear nucleus (H and E X400). 


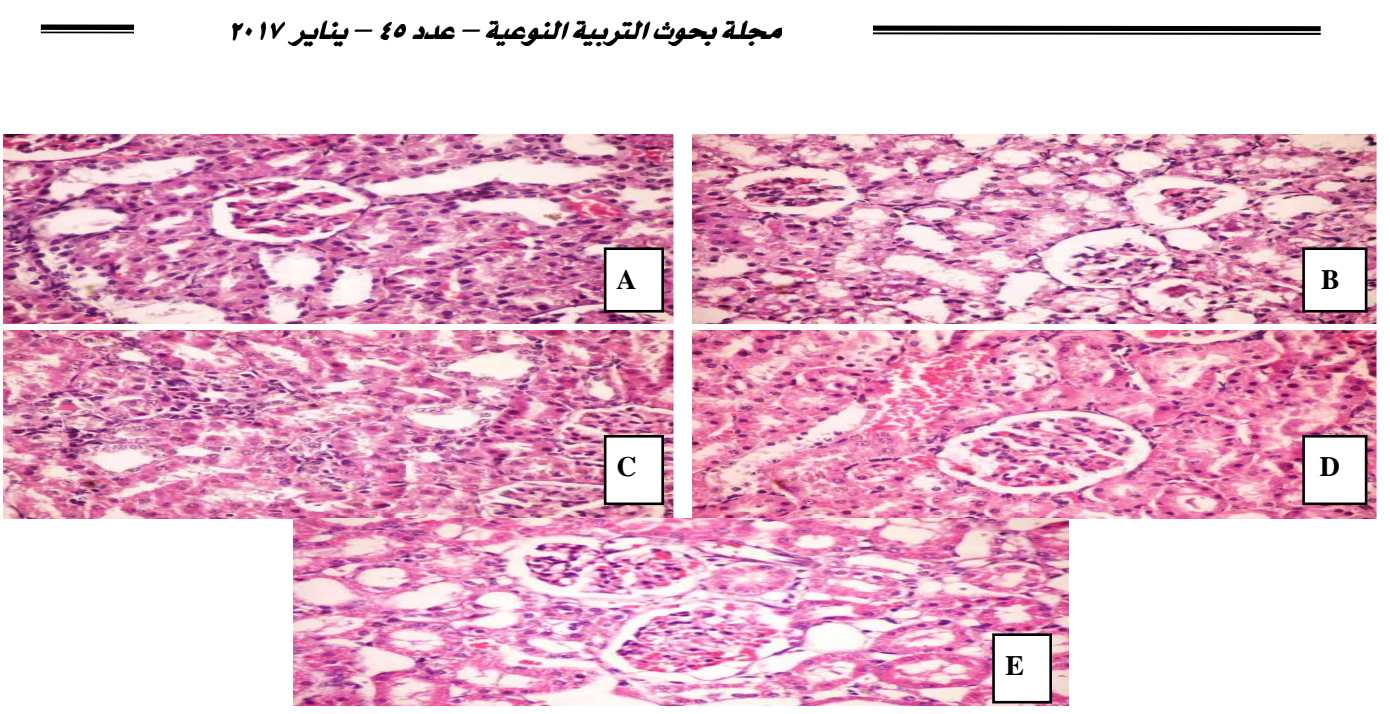

Fig. 6. (A) Renal of normal rat shows normal histological structure of kidney parenchyma ( $H$ and E X400), Bowman's capsules showed distension in glomerular tuft in $\mathrm{CdCl} 2$ rats $(B),(C) \mathrm{CdCl}+50 \mathrm{~g}$ star anise $/ \mathrm{kg}$ diet showed glomerular tuft was atrophied and swelling of Bowman's space (H and E X400), (D) CdCl2 +100g star anise $/ \mathrm{kg}$ diet showed improvement in Bowman's capsules with

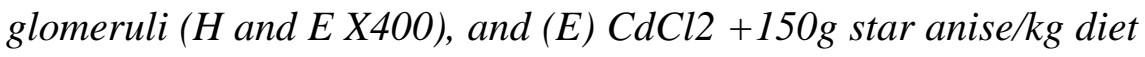
maintained compact glomeruli and well formed renal tubules $(H$ and $E X 400)$. 


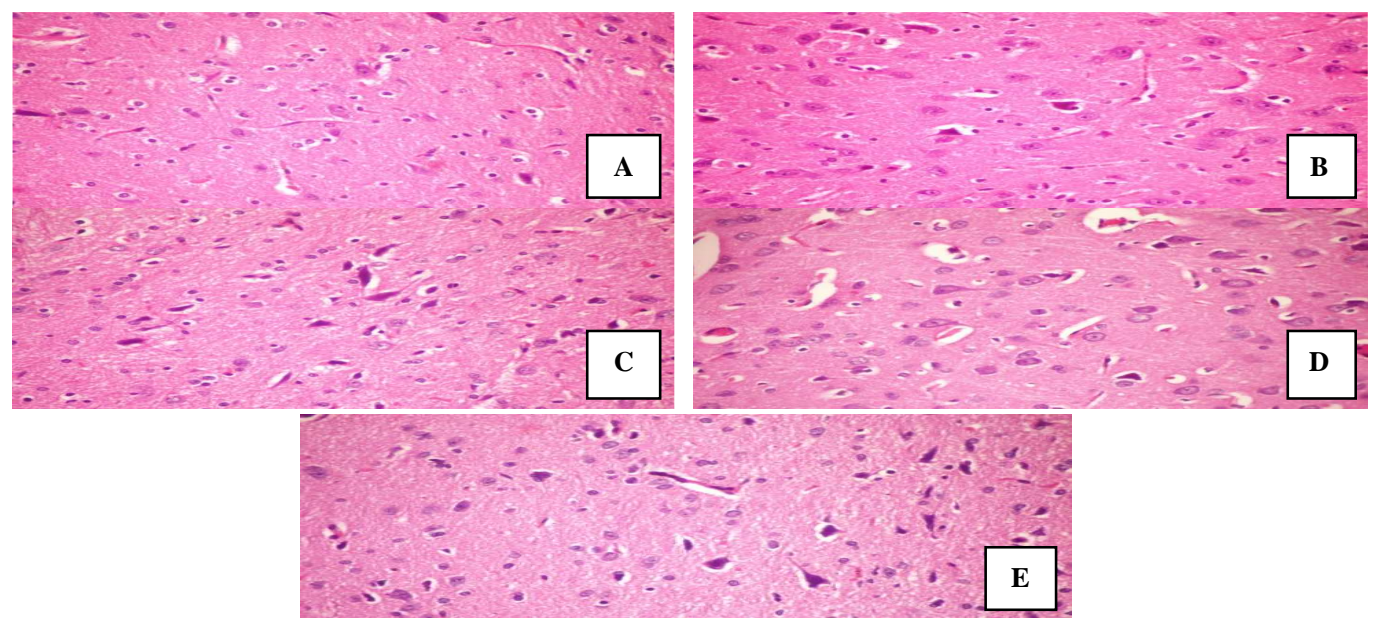

Fig. 7. (A) Normal rat showed no histopathological changes ( $H$ and $E$ X400), CdCl2 exposure caused neuronal degeneration and neuronophagia (H and E X400) (B), CdCl2 +50g star anise/kg diet showed less recovery in brain cells (H and E X400) (C), (D) CdCl2 $+100 \mathrm{~g}$ star anise showed vacuoles in endoneurium (H and $E$ X400) and (E) CdCl2 +150g star anise showed well formed layers, epineurium and endoneurium (H and E X400). 
$\underline{\underline{ }}$ مجلة بحوث التربية النوعية - عدد ه - يناير r. PV

\section{REFERENCS}

Abdel Moneim, A.E.; Bauomy, A.A.; Diab, M.M.; Shata, M.T.; AlOlayan, E.M. and El-Khadragy, M.F. (2014): The protective effect of Physalis peruviana L. against cadmium-induced neurotoxicity in rats. Biol Trace Elem Res, 160: 392-99.

A.O.A.C. (2000): Official Methods of Analysis of tea polyphenols.Mol. Nutr. and Food Res.,

Aboelnaga, S.M.H. (2015): Effect of Some Levels of Cardamom, Clove and Anise on Hepatotoxicity in Rats Caused by CCL4, World Applied Sciences Journal 33 (6): 854-865.

Aggarwal, B.B.; Kunnumakkara, A.B.; Harikumar, K.B.; Tharakan, S.T.; Sung, B. and Anand, P. (2008): Potential of spice-derived phytochemicals for cancer prevention. Planta Med; 74(13): 1560-9.

Alam, R.T.M. and Hendawi, M.Y. (2015): Protective Efficacy of Spirulina platensis Against Cadmium Induced Neurotoxicity in Rats, Global Veterinaria 14 (4): 490-499.

Allian, C.; Poon, L.; Chan, C. and Richmond, W. (1974): Enzymatic determination of total serum cholesterol. Clin. Chem., 20-47.

Aly, S. E.; Sabry, B. E.; Shaheen, M. S. and Hathout, A. S. (2016): Assessment of antimycotoxigenic and antioxidant activity of star anise (Illicium verum) in vitroi, Journal of the Saudi Society of Agriculture Sciences 15:20-27.

Attia, A.M.M.; Ibrahim, F.A.A.; Abd EL-Latif N.A. and Aziz, S.W. (2014): Antioxidant effects of curcumin against cadmium chloride-induced oxidative stress in the blood of rats, Journal of Pharmacognosy and Phytotherapy, 6(3): 33-40.

Ayensu, W.K. and Tchounwou, P.B. (2006): Microarray analysis of mercuryinduced changes in gene expression in human liver carcinoma (HepG2) cells: importance in immune responses. Int J Environ Res Public Health 3,141-173.

Bancroft, J.; Stevens, A. and Turner, D. (1996): Theory and practice of histological technique .4th Ed, New York, Churchill, Livingstone. 
$=$ protective effect of star anise seeds on cadmium induced changes on biochemical parameters of rat $=$

Bi, X.; Soong, Y.Y.; Lim, S.W. and Henry, C.J. (2015): Evaluation of antioxidant capacity of Chinese five-spice ingredients, Int J Food Sci Nutr; 66(3): 289-292.

Bohmer, H. (1971): Micro-determination of creatinine. Clin. Chem. Acta.; 32: $81-85$.

Breitenbach , M. and Eckl, P. (2015): Introduction to Oxidative Stress in Biomedical and Biological Research, Biomolecules, 5, 1169-1177.

Cao, G.; Alessio, H. and Cutler, R. (1993): Oxygen radical absorbance capacity assay for antioxidants. Free Radic Biol Med.; 14:303-311.

Carageorgiou, H.; Tzotzes, V.; Pantos, C.; Mourouzis, C.; Zarros A. and Tsakiris, S. (2004): In vivo and in vitro effects of cadmium on adult rat brain total antioxidant status, acetylcholinesterase, (Na-K-)-ATPase and Mg2-ATPase activities: protection by L-cysteine. Basic Clin Pharmacol. Toxicol., 94: 112-118.

Chapman, D.; Castilla, R. and Campbell, J. (1959): Evaluation of protein in food. I. A. Method for the determination of protein efficiency ratio. Can. J. Biochem. Physiol.; 37: 679-686.

Chatterjee, P.K.; Vinodini N.A.; Anwar A.; Nayanatara, A.K.; Pai, S. R. and Suman, V.B. (2013): Hypolipidemic effect of Moringa oleifera leaf extract in cadmium exposed rats, International Journal of Innovative Research in Science, Engineering and Technology, 2, (9): 4718-4723.

Elgaml, S.A. and Hashish, E.A. (2014): Clinicopathological studies of Thymus vulgaris Extract Against Cadmium Induced Hepatotoxicity in Albino Rats, Global Journal of Pharmacology 8 (4): 501-509.

El-Refaiy, A.I. and Eissa, F.I. (2013): Histopathology and cytotoxicity as biomarkers in treated rats with cadmium and some therapeutic agents, Saudi Journal of Biological Science, 20:265-280.

Fnedewaid, W.T. (1972): Determination of HDL. Clin. Chem., 8:499.

Fossati, P. and Prencipe, L. (1982): Determination of triglycerides, Bicon Diagnostics, made in Germany. Clinical Chemistry, 28: 2077-2078. 
$\underline{\underline{ }}$

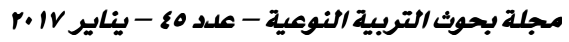

Fossati, P.; Prencipe, L. and Berti, G. (1980): Use of 3.5 dichloro-z-hydroxybenzenesulfonic acid / 4 aminophenazone chromogenic systems in direct enzymic assay of uric acid in serum and urine. Clin. Chem.; 26:227- 231.

Fowler, B.A. (2009): Monitoring of human populations for early markers of cadmium toxicity: a review. Toxicol Appl Pharmacol, 238, 294-300.

Goel, A. (2013): Anticancerous Potential of Plant Extracts and Phytochemicals. J. Biol. Chem. Research. 30, (2): 537-558.

Gong, P.; Chen, F.X.; Ma, G.F.; Feng, Y.; Zhao, Q.Y. and Wang, R. (2008): Endomorpin 1 effectively protects cadmium chloride-induced hepatic damage in mice. Toxicology 251: 35-44.

Gupta, V.K.; Kumar, A.; Siddiqi, N.J. and Sharma, B. (2016): Rat Brain Acetyl Cholinesterase as a Biomarker of Cadmium Induced Neurotoxicity, Open Access J of Tox 1(1): 555-553.

Hao, M.L.; Pan, N.; Zhang, Q.H. and Wang, X.H. (2015): Therapeutic efficacy of chlorogenic acid on cadmium-induced oxidative neuropathy in a murine model, Experimental and Therapeutic Medicine 9: 1887-1894.

Hassan, R.A.; Amin, D.M.; Rahmy, N.A.; Hatem, M.E. and Dessouky, M.I. (2012): Clinicopathological, histopathological and immunological studies on animals exposed to lead and cadmium under experimental conditions. New York Sci J 5: 120-136.

Hew, K.W.; Ericson, W.A. and Welsh, M.J. (1993): A Single Low Cadmium Dose Causes Failure of Spermiation in the Rat. Toxicology and Applied Pharmacology. 121, (1): 15-21.

Hristev, H.; Penkov, D.; Hallak, A.K.; Kirova, M.; Baykov, B. and Biznakov, A. (2007): Serum protein changes in rabbits after chronic administration of lead and cadmium. J Central Euro Agric, 9: 157-162.

Huang, Y.; Zhao, J.; Zhou, L.; Wang, J.; Gong, Y.; Chen, X. (2010): Antifungal activity of the essential oil of Illicium verum fruit and its main component trans-anethole. Molecules. 15(11):7558-69.

Hussaini, J.; Othman, N.A. and Abdulla, M.A. (2013): Antiulcer and Antibacterial Evaluations of Illicium Verum Ethanolic Fruits Extract (IVEFE), The Open Conference Proccedings Journal, (4): 106. 
- protective effect of star anise seeds on cadmium induced changes on biochemical parameters of rat

Jadhav, S.H.; Sarkar, S.N.; Patil, R.D. and Tripathi, H.C. (2007): Effect of subchronic exposure via drinking water to a mixture of eight water contaminating Metals: A Biochemical and histopathological study in male rats. Arch Environ. Contam. Toxicol 53, 667-677.

Kanter, M.; Aksu, B.; Akpolat, M.; Tarladacalisir, Y.T.; Aktas, C. and Uysal, H. (2009): Vitamin $\mathrm{E}$ protects against oxidative damage caused by cadmium in the blood of rats. Eur. J. Gen. Med. 6:154-160.

Kaoud, H.A.; Kamel, M.M.; Abdel-Razek, A.H.; Kamel, G.M and Ahmed, K.A. (2010): Neurobehavioural, neurochemical and neuromorphological effects of cadmium in male rats, Journal of American Science, 6 (5): 189202.

Kasuya, M.; Teranishi, H.; Aoshima, K.; Katoh, T.; Horiguchi, H.; Morikawa, Y. (2000): Water pollution by cadmium and the onset of Itai-itai disease. Water Sci. Technol. 25, 149-156.

Knedel, M. and Boottger, R. (1967): A kinetic method for determination of the activity of pseudo cholinesterase. Klin. Wochenschr, 45: 325-327.

Lalitha, V.; Raveesha, K.A. and Kiran, B. (2010): Antimicrobial activity of Solanum torvum Swart. against important seed borne pathogens of paddy. Iranica J Energy Environ 1(2): 160-164.

Lee, R. and Nieman, D. (1996): Nutritional assessment. $2^{\text {nd }}$ Ed., Mosby, Missoun, USA.

Li, S.; Tan, H.Y.; Wang, N.; Zhang, Z.J.; Lao, L.; Wong, CH and Feng , Y.(2015): The Role of Oxidative Stress and Antioxidants in Liver Diseases, Int. J. Mol. Sci. 16:26087-26124.

Li, S.G.; Wang, D.G.; Tian, W.; Wang, X.X.; Zhao, J.X.; Liu, Z. et al. (2008): Characterization and anti-tumor activity of a polysaccharide from Hedysarum polybotrys Hand.Mazz. Carbohydr Polym, 73:344-50.

Li, W.; Cui, S.W. and Kakuda, Y. (2006): Extraction, fractionation, structural and physical characterization of wheat bd-glucans. Carbohydr Polym 63:408-16. 
Liu, J.; Qian, S.Y.; Guo, Q.; Jiang, J.; Waalkes, M.P. and Mason, R.P. (2008): Cadmium generates reactive oxygen- and carbon-centered radical species in rats: insights from in vivo spin-trapping studies. Free Radic Biol Med, 45, 475-481.

Liu, L.M.; Guo, Z.D. and Zhang, J. (1997): Study on composition of supercritical CO2 fluid extract of Illicium verum Hook. f. J Instrumental Anal, 16(4):24-6.

Madhu, C.S.; Manukumar, H.M.; Thribhuvan, K.R.; Bhimangouda, R.P. (2014): Phytochemical, nutritional and mineral constituents of illicium verum hook (star anise), World Journal of Pharmaceutical Research, 3 (2): 2888-2896.

Matsui, T.; Ito, C.; Itoigawa, M.; Okada, T. and Furukawa, H. (2007): Antiinflammatory activity of phenylpropanoids and phytoguinoids from Illicium species in RBL-2He cells. Planta Med, 73 (7):662-5.

Milton Prabu, S.; Muthumani, M. and Shagirtha, K. (2012): Protective effect of Piper betle leaf extract against cadmium-induced oxidative stress and hepatic dysfunction in rats, Saudi Journal of Biology Sciences, 19 (2): 229239.

Mohamed, H.S.A.A.; Abdelgadir, W.S.; Almagboul, A.Z. I. (2015): Review article: In vitro antimicrobial activity of Anise seed (Pimpinella anisum L.), International Journal of Advanced Research, 3 (1): 359-367.

Morshedi, R.,; Massumeh A. and Kambiz, A.A. (2014): Protective Effects of Zinc Supplementation on Renal Toxicity in Rats Exposed to Cadmium, Jundishapur J Health Sci., 6(3): e21717.

Nishikimi, M.; Rao, N. and Yogi, K. (1972): Colorimetric determination of superoxide dismutase. Biochem. Biophys. Res. Common., 46: 849-854.

Ohkawa, H; Ohishi, N. and Yagi, K. (1979): Assay for lipid peroxides in animal tissues by thiobarbituric acid reaction. Anal Bio, 95: 351-358.

Onwuka, F. C.; Erhabor, O.; Eteng, M. U. and Umoh, I. B. (2010): Ameliorative effect of cabbage extract on cadmiuminduced changes on hematology and biochemical parameters of albino rats, Journal of Toxicology and Environmental Health Sciences, 2 (2): 11-16. 
$=$ protective effect of star anise seeds on cadmium induced changes on biochemical parameters of rat $=$

Oyinloye, B.E.; Ajiboye, B.O.; Ojo, O.A.; Musa, H.M.; Onikanni, S.A. and Ojo, A.A. (2016): Ameliorative potential of Aframomum melegueta extract in cadmiuminduced hepatic damage and oxidative stress in male Wistar rats, Journal of Applied Pharmaceutical Science, 6 (7): 094-099.

Park, S.H.; Sung, Y.Y.; Nho, K.J. and Kim, H.K. (2015): Protective activity ethanol extract of the fruits of Illicium verum against atherogenesis in apolipoprotein E knockout mice, BMC Complementary and Alternative Medicine, 15:232.

Patton, C. and Crouch, S. (1977): Determination of serum urea enzymatically. J. of Ana. Chem.; 49: 464 - 469.

Rajkumar, J. S. I. and Milton, M. C. J. (2011): "Biochemical markers of oxidative stress in mugil cephalus exposed to cadmium, copper, lead and zinc," International Journal of Pharma and Bio Sciences, 2 (3): 41-50.

Reeves, P.; Nielson, F. and Fahmy, G. (1993): Reports of the American Institute of Nutrition, Adhoc Wiling Committee on reformulation of the AIN 93. Rodent Diet. J. Nutri.; 123: 1939-1951.

Reitman, S. and Frankel, S. (1957): Determination of serum alanine and aspartate aminotransferases (ALT \& AST). Clin .Path. Am. J., 28: 57-63.

Renugadevi, J. and Prabu, S.M. (2010): Cadmium-induced hepattotoxicity in rats and the protective effect of naringenin. Experimental snd Toxicologic Pathology, 62 (2):171-181.

Rogalska, J.; Brzóska, M. M.; Roszczenko, A. and MoniuszkoJakoniuk, J. (2009): Enhanced zinc consumption prevents cadmium-induced alterations in lipid metabolism in male rats. Chemico-Biological Interations, 177, 142152.

Russo, E. (2001): Handbook of Psychotropic Herbs: A scientific analysis of herbal remedies for psychiatric conditions. The Haworth Herbal Press, Inc.

Satarug, S.; Garrett, S.H.; Sens, M.A. and Sens, D.A. (2010): Cadmium, environmental exposure and health outcomes. Environ Health Perspect, 118: 182-190.

Shagirtha, K.; Muthumani, M. and Milton, S. (2011): Melatonin abrogates cadmium induced oxidative stress related neurotoxicity in rats. Eur. Rev Med. Pharmacol. Sci., 15: 1039-50. 
Shu, X.; Liu, X.; Fu, C. and Liang, Q. (2010): Extraction, characterization and antitumor effect of the polysaccharides from star anise (illicium verum Hook. f.). J Med Plants Res., 4:2666-2673.

Singh, C.R. (2011): Antimicrobial effect of callus and natural plant extracts of Premna serratifolia L. Int J Pharm Biomed Res; 2(1): 17-20.

Singh, R.; Devi, S. and Gollen, R. (2015): Role of free radical in atherosclerosis, diabetes and dyslipidaemia: larger-than-life, Diabetes Metab Res Rev; 31: 113-126.

Skipper, A.; Sims, J.N.; Yedjou, C.G. and Tchounwou, P.B. (2016): Cadmium Chloride Induces DNA Damage and Apoptosis of Human Liver Carcinoma Cells via Oxidative Stress, Int. J. Environ. Res. Public Health, 13:88-93.

Slechta, D.A. and Pokora, M.J. (1995): Lead induced changes in muscarinic cholinergic sensitivity, Neurotoxicology, 16: 337-348.

Snedecor, G.W. and Cochran, W.G. (1967): Statistical Methods; $7^{\text {th }}$ Ed., The Lowa State University Press., Ames, Lowa, U.S.A.

Somade, P. M.; Adnaik, R. S.; Mohite, S. K. and Magdum, C.S. (2014): Protective role of cucumis melo against cadmium induced oxidative neurotoxicity in mice, International Journal of Universal Pharmacy and Bio Sciences 3(4):269-279.

Sultana, R.; Perluigi, M. and Butterfield, D.A. (2013): Lipid peroxidation triggers neurodegeneration: A redox proteomics view into the Alzheimer disease brain, Free Radical Biology and Medicine 62:157-169.

Sung, Y.Y.; Kim, Y.S. and Kim, H.K. (2012): Illicium verum extract inhibits TNF-a and IFN-ginduced expression of chemokines and cytokines in human Kerationocytes. J Ethnopharmacol. 144(1):182-9.

Toman, R.; Adamkovicova, M.; Hluchy, S.; Cabaj, M. and Golian, G. (2011): Quantitative analysis of the rat testes after an acute cadmium and diazinon administration. Sci Papers: Animal Science and Biotechnologies, 44: 188191.

Usuda, K.; Kono, K.; Ohnishi, K.; Nakayama, S.; Sugiura, Y.; Kitamura, Y.; Kurita, A.; Tsuda, Y.;Kimura, M. and Yoshida, Y. (2011): Toxicological aspects of cadmium and occupational health activities to 
$=$ protective effect of star anise seeds on cadmium induced changes on biochemical parameters of rat prevent workplace exposure in Japan: A narrative review. Toxicol Ind Health, 27: 225-233.

Valko, M.; Morris, H. and Cronin, M.T.D. (2005): Metals, Toxicity and Oxidative Stress, Current Medicinal Chemistry, 12:1161-1208.

Vecchio, M.G.; Gulati, A.; Minto, C. and Lorenzoni, G. (2016): Review article: Pimpinella Anisum and Illicium Verum: The Multifaceted Role of Anise Plants, The Open Agriculture Journal, 10:81-86.

Wang, G.W.; Hu, W.T.; Huang, B.K. and Qin, L.P. (2011): Illicium verum: a review on its botany, traditional use, chemistry and pharmacology. J Ethnopharmacol. 136(1):10-20.

Yadav, A.S. and Bhatnagar D. (2007): Chemo-preventive effect of Star anise in N-nitrosodiethylamine initiated and phenobarbital promoted hepatocarcinogenesis. Chem Biol Interact., 169 (3): 207-14.

Yang, C.H.; Chang, F.R.; Chang, H.W.; Wang, S.M.; Hsieh, M.C. and Chuang, L.Y. (2012): Investigation of the antioxidant activity of Illicium verum extracts, Journal of Medicinal Plants Research, 6(2): 314-332. 


\section{التأثير الوقائي لبذور اليانسون النجمى على التغيرات التى يمدثها الكادهيوم فى القياسات البيوكيسيائية للفئران}

\section{الملخص العرببي}

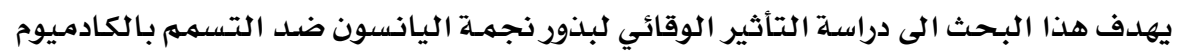

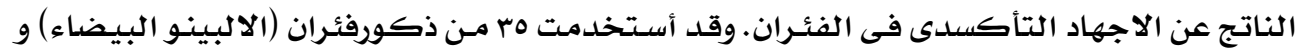

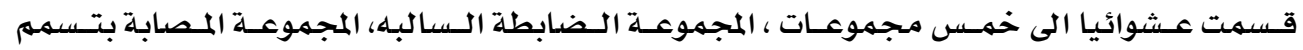

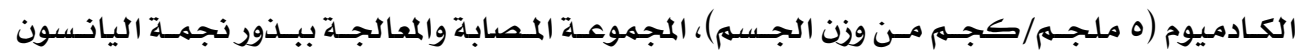

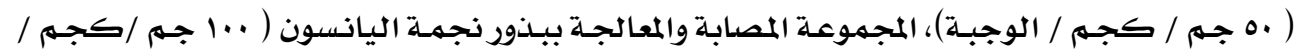

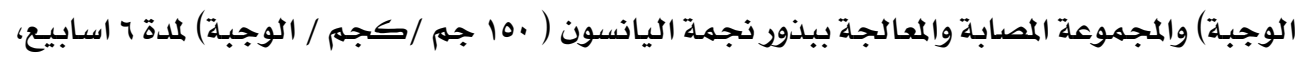

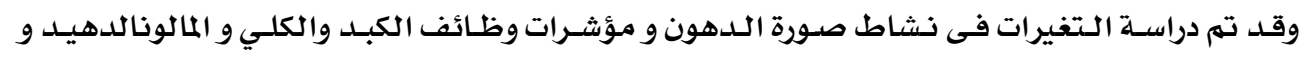

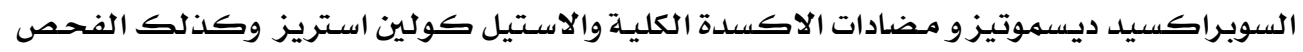
الهستولوجى لكلامن الكبد والكلى والمخح.

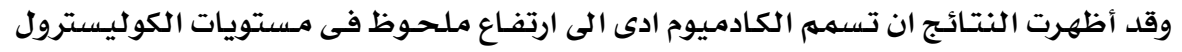

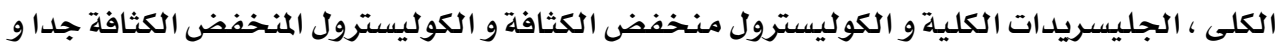

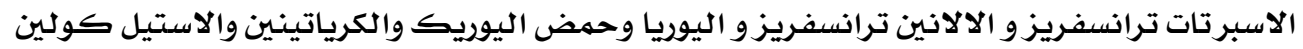

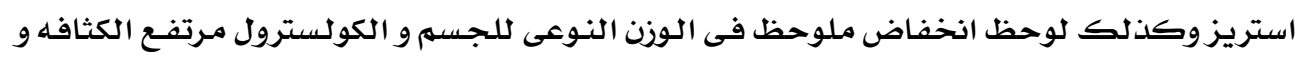

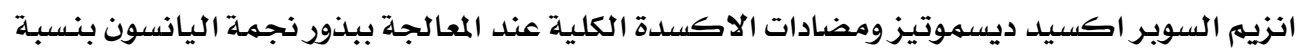

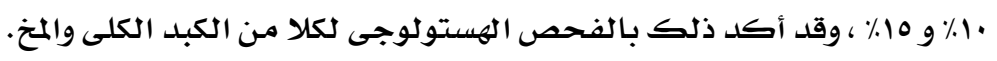

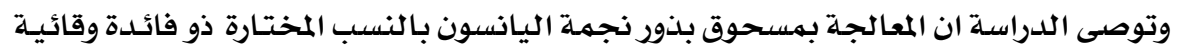

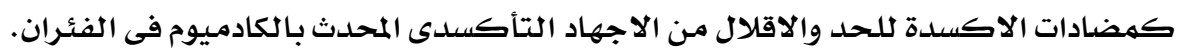

